UDC: 341.171(4-672EУ:497-15)

\title{
ПОЛИТИКА РАСШИРЕНИЯ ЕВРОПЕЙСКОГО СОЮЗА НА БАЛКАНАХ
}

\author{
Александар Симонов \\ 2 курс магистратуры, Факультет Международных Отношений - Санкт- \\ Петербургский Государственный Университет \\ simonov_aleksandar@yahoo.com
}

\begin{abstract}
Аннотация
Политика расширения Европейского Союза (ЕС) постоянно меняется. После изменений в методологии расширения вопрос снова стал актуальным. Для определения эффективности изменений нужно провести дополнительные эмпирические исследования. Целью исследования является изучение эффективности изменений в политике расширения Европейского Союза. Результаты анализа показали неодинаковое поведение ЕС по отношению к странам-кандидатам. Это указывает на необходимость справедливого отношения к кандидатам на Балканском полуострове.
\end{abstract}

Ключевые слова: Европейский Союз, интегращия, проиесс, Западные Балканы, методология

\section{EUROPEAN UNION ENLARGEMENT POLICIES IN THE BALKANS}

\author{
Aleksandar Simonov \\ Master studies, Saint Petersburg State University \\ simonov_aleksandar@yahoo.com
}

\begin{abstract}
The enlargement policy of the European Union (EU) is constantly changing. After the enlargement methodology was revised, the question became of current interest. However, very little empirical research has been carried out to determine the effectiveness of changes. The aim of this study was therefore to investigate the effectiveness of changes in enlargement policies. The results of the analysis showed the uneven behavior of the EU in relation to the candidate countries. This suggests the need for fair approach to candidates on the Balkan Peninsula.
\end{abstract}

Keywords: European Union, integration, process, Western Balkans 


\section{Введение}

Согласно цели данной работы, исследование основано на классических методах: историческом методе, системном анализе, сравнительном анализе, методе индукции и дедукции, контент- и интент-анализе.

Исторический и сравнительный анализ был проведён с целью подтвердить гипотезу о неодинаковом поведении Европейского Союза в отношении странкандидатов на членство в организации, нарушающем принцип равенства. Предполагается, что политика расширения отклоняется от ценностей ЕС и основана на политических соглашениях и политических решениях.

Анализ позиции стран ЕС в отношении проведения и оценки странкандидатов на основе контент- и интент-анализа является основой для подтверждения гипотезы о том, что, члены ЕС используют свою позицию и влияют на решения в отношении оценки стран-кандидатов на вступление, чтобы защитить свои национальные интересы в двусторонних спорах. Одновременно высказывается предположение о злоупотреблении правом вето, что подразумевает его использование для защиты своих интересов, что не имеет какого-либо отношения к ценностям и интересам ЕС.

Материалом для системного, а также контент и интент анализа является методология расширения ЕС, принятая в феврале 2020 года. Гипотеза, рассматриваемая в данной части исследования, заключается в предположении о том, что государства должны полностью основывать свою политику на выполнении требований ЕС, теряя право защищать свои национальные интересы. Анализ усложнения и повышения требований для стран Западных Балкан (ЗБ) основан на документах, принятых ЕС.

\section{1. Характеристики и изменения в политике расширения Европейского Союза}

Путь к европейской интеграции открыла Декларация Шумана. Значение декларации выходило далеко за рамки отношений двух бывших противников в войне. Она призывала к созданию «общей основы экономического развития, которая явится первым шагом к Европейской федерации» ${ }^{1}$.

Объединения шли гораздо дальше, чем в традиционных международных организациях. Они предполагали передачу части государственного суверенитета на наднациональный уровень и ставили целью формирование сплоченного сообщества с общей судьбой. «На протяжении всей своей истории ЕС переживал как успешные, так и весьма сложные периоды. Тем не менее, в долгосрочной перспективе интеграция продолжала развиваться. Европейские сообщества последовательно двигались сначала к таможенному союзу, далее - к

${ }^{1}$ Борко, Ю., [Электронный ресурс] История развития Европейского Союза / Ю. Борко, О. Буторина. М. , 2009 -23 с [Электронный ресурс] URL: https://mgimo.ru/uploads/files/ Borko_Butorina_Istoriya_ES.pdf (дата обращения: 02.05.2020). 
единому общему рынку и, наконец, к валютному союзу»².

Рассматривая структуру самого союза «расширение в основном не подпадает под сферу внешней политики. Скорее, это связано с архитектурой самого Сообщества, поскольку его целью является привлечение третьих стран в Союзе. Тем не менее расширение в значительной степени касается внешней политики и почти всегда было существенно связано с геополитикой. Одновременно является ключевым инструментом так называемой «мягкой силы» союза, которая считается самым мощным оружием его внешней политики». ${ }^{3}$

Законного права на вступление нет, государство могло подать заявку на членство, но союз не обязан принимать заявку. Кроме того, требование к демократии включает в себя хорошо известные «критерии» членства, и именно на основе этих критериев государства-члены оценивают каждую кандидатуру, хотя и со значительным запасом интерпретации ${ }^{4}$. Практически после соответствия критериям Союз обязан продвигать статус государства, история показала, что однажды достигнутый статус не может быть потерян. На протяжении всего периода переговоров, условия и сроки принятия, внедрения и соблюдения всех правил ЕС установлены и разделены на 35 различных глав 5 .

Тем не менее, в духе основателей союза расширение, несомненно, основывалось на убежденности в том, что Европа формирует «семью» с общими историческими и цивилизационными корнями, основанную на общих демократических и социальных ценностях. Они отражаются в свободах, институтах и социальной модели, которые защищаются и развиваются. Все европейские народы имеют свое место в этом союзе 6 .

2 Там же.

${ }^{3}$ Walldén, A.S., [Электронный ресурс] - The demise of EU enlargement policy - 2017 2.c. http://www.eliamep.gr/wp-content/uploads/2017/03/Enlargement-policy-1701-fin.pdf (дата обращения : 02.05.2020)

4 Любое европейское государство может подать заявку на вступление в Сообщество» (статья 237). Этот пункт повторяется с тех пор во всех договорах, которые наследовали Римский договор. В Амстердамском договоре (1997 г.) было добавлено, что страна, которая желает присоединиться, должна быть демократической, и это условие было дополнительно определено в действующем Договоре о Европейском союзе (TEU) (статья 49).

${ }^{5}$ Conditions for Membership [Электронный pecypc] European Neighborhood Policy and Enlargement Negotiations - European Commission”. 2018 URL: https://ec.europa. eu/neighbourhood-enlargement/policy/conditions-membership en (дата обращения : 03.05.2020)

${ }^{6}$ Walldén, A.S., [Электронный ресурс] - The demise of EU enlargement policy - 2017 2.c. http://www.eliamep.gr/wp-content/uploads/2017/03/Enlargement-policy-1701-fin.pdf (дата обращения :_02.05.2020) 
С 1990-х годов стал очевиден прогресс в сфере общей внешней политики и обороны. В настоящее время интеграция в той или иной степени затрагивает практически все стороны общественной жизни государств-членов. Успех интеграции напрямую связан с особой политической культурой и правовой системой ЕС. Неизбежные противоречия между отдельными странами и группами интересов преодолеваются благодаря активному диалогу и неизменной нацеленности на нахождение компромисса. Ежедневное функционирование ЕС обеспечивает создававшаяся десятилетиями система институтов, норм, методов и процедур. Эта система позволяет согласовывать интересы разных сторон при принятии решений, а затем контролировать их исполнение ${ }^{7}$. Вопрос политики расширения ЕС вызывает бурные обсуждения как среди жителей и политиков стран - членов, так и среди тех, кто рассматривает себя в качестве потенциальных участников европейского объединения.

Остается фактом, что политика расширения ЕС постоянно меняется, основываясь надоговорах, мировых политическихтенденциях, геополитических факторах и так далее. Рассматривая политики расширения ЕС в регионе ЗБ, то постоянно открываются дискуссии об изменениях в политике расширения ЕС, и нередко возникают вопросы об усложнении процесса расширения в отношении к этих стран, нарушая ценностей который союз взял на себя.

Процесс расширения ЕС не является только территориальным расширением, включая прав, привилегий и обязательств из членства, он представляет долгим, утомительным, бюрократическим и техническим процессом который включает гораздо больше обязанностей в себе. По словам Кристофа Хиллиона, «расширение также вызывает новые политические требования ЕС и меняет свое институциональное функционирование влияя на его правовой корпус» ${ }^{8}$. Таким образом, процесс все больше и больше политизирован и требует, чтобы организация работала под «всесторонним одобрением» процедуры, обеспечивающем прием новых членов только тогда, когда они могут продемонстрировать, что они будут в состоянии сыграть свою роль полностью»9. Будущие страны-члены должны соблюдать все стандарты и правила ЕС. Кроме того, будущие государства-члены должны иметь согласие институтов ЕС и других государств-членов ЕС, а также согласие своих граждан, полученное путем выраженного одобрения парламента или через общенациональный референдум. Соблюдать правила и выраженное согласие

\footnotetext{
7 Борко, Ю. ор. cit. note 1, p.23.

${ }^{8}$ Christophe, H., "EU Enlargement" / H. Christophe - Swedish Institute for European Policy Studies; OUP CORRECTED PROOF - 2011 - p.187-216.

${ }^{9}$ Conditions for Membership - European Neighborhood Policy and Enlargement Negotiations - European Commission”. 2018 URL: https://ec.europa.eu/neighbourhoodenlargement/policy/conditions-membership_en (дата обращения : 04.05.2020)
} 
всех вовлеченных сторон недостаточно для доступ страны в $\mathrm{EC}^{10}$.

В частности, Договор о Европейском Союзе устанавливает условия (статья $49)$ и принципы (статья 6 (1)), к которым любая страна желающая стать членом $\mathrm{EC}$, должна соответствовать ${ }^{11}$. В 1993 г. Европейский совет в Копенгагене установил эти критерии, известные как «Копенгагенские критерии». Два года спустя Мадридский Совет Европы продолжил совершенствовать эти критерии.

Важно подчеркнуть то, что ЕС должен иметь возможность принимать новых членов в организацию без ущерба для государств в процессе интеграции. Но, дополнительные условия для членства были изложены в «Процессе стабилизации и ассоциации» (ПСА). ПСА создал эти условия для содействия региональному сотрудничеству и добрососедству отношения между странами ЗБ с долгосрочным намерением стабилизировать политический регион и создание зоны свободной торговли. ПСА устанавливает «общие» политические и экономические цели», но оценка прогресса основывается на собственных заслугах каждой страны ${ }^{12}$.

Новый контроль привел к тому, что в процессе расширения доминируют позиции ЕС, а в некоторых случаях национальные программы являются заложниками. «Разработка ПСА не только замедлила процесс вступления, но и поставила новые вопросы относительно достоверности, обязательств ЕС в отношении стран-кандидатов, и следовательно, эффективности «признанных преобразующих сил» политики расширения. Новый контроль привел к тому, что в процессе расширения доминируют позиции ЕC, а в некоторых случаях национальные программы являются заложниками» ${ }^{13}$. Кроме того, ЕС расширил роль обусловленности на всех этапах процесса расширения. В частности, в попытке смягчить проблемы, связанные с плохо подготовленными государствами-кандидатами и разочарованием общественности, ЕК и Совет ЕС согласились принять «Стратегию расширения, основанная на консолидации, обусловленности и коммуникации» ${ }^{14}$.

Согласно документа ЕК, «контрольные показатели - новый инструмент, введенный в результате уроков, извлеченных из пятого расширения. Их цель - улучшить качество переговоров, стимулируя страны-кандидаты к 10 Там же.

${ }^{11}$ Accession Criteria (Copenhagen Criteria) - EUR-Lex”. 2018. Eur-Lex. europa.eu. URL: http://eurlex.europa.eu/summary/glossary/accession_criteria_copenhague.html (дата обращения : 05.05.2020)

12 Conditions for Membership - European Neighborhood Policy and Enlargement Negotiations - European Commission". 2018 URL: https://ec.europa.eu/neighbourhoodenlargement/policy/conditions-membership_en (дата обращения : 04.05.2020)

${ }^{13}$ Christophe, H., The Creeping Nationalization of The EU Enlargement Policy / H. Christophe - Swedish Institute for European Policy Studies - Report No. 6 - 2010.

14 Там же. 
проведению необходимых реформ на ранней стадии. Контрольные показатели измеримы и связаны с ключевыми элементами главы «acquis communautaire» ${ }^{15}$. Невыполнение этих предварительно определенных контрольных показателей может привести к приостановке переговоров и затормозить переговоры на неопределенное время. Переговоры о присоединении почти всегда зависят от выполнения конкретных условий. Часто условия, налагаемые ЕС или государством-членом, ущемляют национальные интересы стран-кандидатов, что делает интеграцию невыгодной для страны-кандидата.

$\mathrm{C}$ точки зрения стран-членов $\mathrm{EC}$, процесс работает как аварийный тормоз для потенциального расширения, отдавая им больше контроля над тем, кто вступает в Союз. Однако этот контроль привел к непредсказуемости процесса и злоупотреблению властью во многих нынешних государствах-членах. Вновь созданные условия фактически неравны по сравнению с условиями, которые государства выполняли в ходе предыдущих расширений. Одновременно изменения указывают на то, что стране с самыми скромными возможностями придется пройти самый сложный путь интеграции. Независимо от эффективности развивающегося процесса расширения, остаются параметры, которые любая страна-кандидат, обязана выполнить их в процессе перехода к полноправному членству.

\section{2. Исторический обзор расширения Европейского Союза}

Расширение ЕС - процесс, который продолжается на протяжении всей его истории. Начиная с 1973 года по сегодняшний день выделяется несколько циклов.

Первое расширение произошло в 1973 году с присоединением трех стран: Соединенного Королевства Великобритании и Северной Ирландии, Дании и Ирландской Республики ${ }^{16}$. Интересно отметить, что Соединенное Королевство было приглашено стать частью Европейских сообществ с момента их создания. Однако из-за своего специфического геостратегического положения и исторических связей Великобритания отказалась участвовать в этом проекте объединения Европы на начальном этапе. Великобритания даже инициировала подписание Договора о создании Европейской организации свободной торговли, в которой не было бы наднациональных элементов в качестве альтернативы ЕС. Позже Великобритания признала необходимость участия в интеграционном процессе, чтобы иметь право голосовать и влиять на решения в Европейских сообществах, поэтому она решила подать заявку на членство. Заявление было отклонено из-за позиции тогдашнего президента Франции Шарля де Голля, который наложил вето на вступление 1963 года и объявил то же самое для

15 Там же.

${ }^{16}$ The history of the European Union [Электронный ресурc] -URL: The history of the European Union | European Union (дата обращения : 05.05.2020) 
второй британской заявки на членство в 1967 году. Эта позиция президента Франции была оправданной по определенным причинам.

Ирландская Республика, с другой стороны, просто следовала за Великобританией благодаря того, что их экономика была в значительной степени зависимой от Британии. Также за их желании продолжать свои связи с Северной Ирландией, которая является частью Королевства. ${ }^{17}$ Схожая ситуация была с Данией, чья экономика была тесно связана с экономикой Великобритании. Аналогичная ситуация сложилась в Норвегии, которая не стала частью ЕС из-за отрицательных результатов референдума, организованного в первой половине 1972 года.

Разница во времени между вторым (Греция, 1981 г.) и третьим (Испания и Португалия, 1986 г.) циклом расширения была невелика, и эти два цикла расширения нередко рассматриваются как один. Относительно критериев членства в 1981 году, более чем очевидно, что копенгагенские критерии еще не существовали, и основное требование к демократической системе было выполнено, по крайней мере, формально. До 1974 года Греция управлялась военной хунтой, и государство подало заявку на членство в ЕС в 1975 году $^{18}$. Хотя были некоторые замечания о готовности Греции к членству из-за геополитических моментов в холодной войне, а также потому, что Европа воспринимала Грецию как колыбель демократии, поэтому она стала членом ЕС в 1981 году ${ }^{19}$. Таким образом, Греция стала моделью, на которую стали ссылаться Испания и Португалия, государства, которые также имели недемократические правительства. Испания подала заявку на членство еще в 1962 году, которая была отклонена из-за того, что Испанией управлял Франсиско Франко ${ }^{20}$. После его смерти в 1975 году начались демократические процессы в Испании. Между тем Португалия также имела опыт работы с не демократическим правительством, названным Estado Novo (новое государство). Перемены произошли в результате революции 1974 года. За относительно короткий период времени эти страны стали членами ЕС.

Следующий цикл расширения произошел в 1995 году. Австрия, Финляндия и Швеция признали необходимость их интеграции в Союз прежде всего с точки

${ }_{17}$ Маролов, Д., Проширување на ЕУ - Историски приказ и моментална состојба / Д. Маролов, С. Стојановски - Универзитет „Гоце Делчев” Штип - 2018

${ }^{18}$ Ministry of foreign affairs Directorate for EU affairs Republic of Turkey - Enlargement of the European Union

${ }^{19}$ Leki, C., The accession of Greece, Greece in Europe: a short history/ C. LikI -

[Электронный ресурc]- URL : https://www.theguardian.com/world/2015/jul/03/greece-ineurope-a-short-history - 2016 (дата обращения : 05.05.2020)

${ }^{20}$ Moreno, A.J. Franco's Spain and the European Communities / A.J. Moreno

- [Электронный ресурc] - http://www.europarl.europa.eu/RegData/etudes/

STUD/2015/563509/EPRS_STU(2015)563509 EN.pdf, (дата обращения : 05.05.2020) 
зрения экономических выгод для их национальных экономик ${ }^{21}$. Тем временем произошли многочисленные события, которые изменили международную арену. Блок социалистических государств и Организация Варшавского договора больше не существовали в Европе, и с ними железный занавес прекратил свое существование. С одной стороны, такие государства, как СССР, Югославия и Чехословакия распались и перестали существовать, с другой стороны, произошло объединение двух германских государств. Самое последнее событие имеет большое значение для расширения ЕС. Именно, с объединением двух немецких государств бывшая Восточная Германия автоматически стала частью ЕС в 1990 году ${ }^{22}$. Следовательно, воссоединение Германии является фактом, который нельзя игнорировать, когда речь идет о расширении ЕС, не представляя классическое расширение с новым государством-членом, в данном случае это конкретное расширение путем объединения государства-члена с государством, не являющимся членом.

Потребуется почти десятилетие, чтобы достичь четвертого (или пятого, если рассматриваем расширение Испании и Португалии в качестве отдельного цикла) цикла расширения 2004 года. Крупнейшее расширение в истории ЕС с десятью новыми членами: Чехией, Словакией, Венгрией, Словенией, Польшей, Латвией, Литвой, Эстонией, Кипром и Мальтой. Некоторые из стран принадлежали к бывшему Варшавскому договору, другие были частью бывшего Советского Союза со статусом союзных республик. Социалистическая система управления в этих странах оставила сильные следы и усложнила путь перехода системы к рыночной экономике и демократизации. Членство Словении, с другой стороны, было важным потому, что давало положительный сигнал другим странам бывшей Югославии получить возможность стать частью европейской семьи.

Тем временем членство Кипратакже означало импорт «кипрской проблемы» как проблемы внутри ЕС. А именно, остров, имеющий стратегическое значение, который де-факто разделен, так как на его территории находится Турецкая республика Северного Кипра, признанная только Турецкой Республикой. «Хотя были некоторые надежды на то, что предложение о членстве в ЕС мотивирует и объединит греческую и турецкую часть острова, условно говоря, остается фактом, что Кипр вступил в ЕС как разделенный остров» ${ }^{23}$. Турецкая Республика Северного Кипра не признана членами ЕС, но фактическая ситуация на местах показывает, что центральное правительство не может обеспечить контроль над той частью острова, где объявлена Республика Северного Кипра. Ирония заключается в том, что часть территории государства-члена, контролируется

21 The history of the European Union [Электронный ресурc] -URL: https://europa.eu/ european-union/about-eu/history_en (дата обращения : 05.05.2020)

22 Маролов, Д. ор. cit. note 18 p./

23 Маролов, Д. ор. cit. note 18 p./. 
армией страны, которая является кандидатом на вступление в ЕС. Такие проблемы, а также проблемы, которые существовали при переговорах с новыми десятью членами, безусловно, способствовали растущей обеспокоенности по поводу процесса и политики расширения. В то же время не следует забывать, что именно это расширение дало сильный сигнал, что Западная и Восточная Европа наконец-то объединятся.

В 2007 году произошло еще одно расширение на юго-восток Европы. Речь идет о присоединении Болгарии и Румынии. Государства подали свои заявки еще в 1995 году. Тем не менее, в докладе ЕК о мониторинге за 2006 год, четко продемонстрирована необходимость этим странам добиться прогресса во многих сегментах судебной системы, борьбе с коррупцией и организованной преступностью, и данные сегменты продолжали отслеживаться ${ }^{24}$. Таким образом, после официального приема ЕК продолжала контролировать страны, прежде всего в сфере верховенства права ${ }^{25}$. В связи с этим возникли многочисленные сомнения относительно готовности стран к членству и уровня выполнения копенгагенских критериев. Вступление Болгарии и Румынии в ЕС не означало их полной интеграции. Таким образом, хотя страны взяли на себя юридическое обязательство по интеграции в Шенгенскую зону, этого не произошло в течение нескольких лет после их вступления в ЕС.

В 2013 году последнее расширение произошло с Республикой Хорватия. С момента получения статуса официального кандидата в 2004 году, ЕС занял более жесткую переговорную позицию с Хорватией, закрывая главы 23 и 24, которые касаются «Судебных и основных прав» и «Справедливости, свободы и безопасности». Требования ЕС, связанные с верховенством права, были сосредоточены главным образом на реформе судебной системы, полиции и прокуратуры, исходя из предположения, что повышение эффективности работы государственных учреждений является способом повышения правовой определенности в целевой стране. ${ }^{26}$ Урегулирование пограничного спора со Словенией и другими соседями играло ключевую роль в процессе интеграции ${ }^{27}$. В отличие от пограничных споров с другими соседями, спор из-за «Пиранского

24 Monitoring report on the state of preparedness for EU membership of Bulgaria and Romania, URL - http://news.bbc.co.uk/2/shared/bsp/hi/pdfs/26_09 06 fullreport.pdf, (дата обращения : 06.05.2020)

25 Pop, V. EU commission defends Romania-Bulgaria monitoring project / V. Pop [Электронный ресурс] , URL - https://euobserver.com/justice/29743, (дата обращения : 06.05.2020)

${ }^{26}$ Policy Department, Directorate-General for External Policies - The Western Balkans and EU Enlargement: Lessons learned, ways forward and prospects ahead / European Union, 2015

${ }^{27}$ Interim report from the commission to the council and the European parliament on reforms in Croatia in the field of judiciary and fundamental rights (negotiation chapter 23), 
залива» пришлось решать из-за того, что Словения уже была членом ЕС она угрожала и даже блокировала переговоры ЕС с Хорватией.

\section{3. Политика расширения ЕС на Балканах - институциональные} изменения и усложнения

Европейская интеграция почти повсеместно признана ключевой стратегией достижения стабильности и развития ЗБ. Европейские политики полагают, что более широкое участие Европы на ЗБ может оказать положительное и долгосрочное воздействие на управление этнополитическими конфликтами. ЕК определила перспективу членства в ЕС как «окончательную стратегию предотвращения конфликтов» и взяла на себя обязательство сохранять и наращивать свое активное присутствие в регионе» ${ }^{28}$. Академический консенсус заключается в том, что более широкое участие ЗБ в европейских институтах является необходимым условием для стабилизации ${ }^{29}$. Но реализация идеи столкнулась с множеством препятствий в ее реализации.

Официальным моментом, после которого начинается интеграция западно-балканских государств, является подписание соглашение о ПСА. ПСА специально направлен на оказание помощи каждой из стран ЗБ в соблюдении соответствующих критериев ЕС. Однако единственным стимулом, который ПСА отказался предоставить, было явное обещание членства в ЕС. В 2000-ом году совет ЕС в Санта-Мария-да-Фейра заявил, что страны ПСА были «потенциальные кандидаты», которые неоспоримо представляли собой продвижение по сравнению с региональным подходом, но не прорыв, который прошел весь путь ${ }^{30}$. ПСА был нацелен на региональный подход ЕС, состоящий из измененных и новых предложений для государств ЗБ, включая усиление либерализации торговли, улучшение финансовой и экономической помощи, регулярный политический диалог, сотрудничество в области юстиции и внутренних дел и, в частности, новую, специально разработанную категорию договорных ПСА. Инструменты, охватываемые ПСА, открыты для всех стран региона на равных условиях. Однако их фактическая доступность по-прежнему зависит от соблюдения каждой страной установленных общих и специфических для страны условий. Несмотря на то, что подход ПСА базируется на общих политических и экономических условиях, он достаточно гибок, чтобы позволить каждой стране двигаться вперед в своем собственном темпе. На Балканском саммите в Салониках было признано, что ПСА останется основой

${ }^{28}$ European Commission, Western Balkans: Prospect of EU Membership Incites Peace in the Western Balkans, 2006, p. 8

29 Batt et al. The Western Balkans: Moving On / Batt - Chaillot Paper №. 70, Institute for Security Studies, Paris, - 2003

30 Anastasakis, O. EU Conditionality in South East Europe: Bringing Commitment to the Process / O. Anastasakis, D. Bechev- Oxford, SEESP - 2003 
для европейского курса стран ЗБ, «вплоть до их будущего присоединения» . $^{31}$

Более поздние заседания Европейского Совета способствовали дальнейшему развитию европейского военного, гражданского и политического потенциала и углублению координации и сотрудничества с другими институтами. Рамочное соглашение, подписанное Верховным представителем $\mathrm{EC}$ по Общей внешной политике и политики безопасности Хавьером Соланой, и генеральным секретарем НАТО лордом Робертсоном в 2003 году, регулировало доступ ЕС к активам НАТО. Сотрудничество между этими двумя институтами вытекает из общих проблем безопасности и общего членства, при этом ряд государств ЕС также являются членами НАТО. В результате этих действий произошло разделение обязанностей. ЕС все больше внимания уделяет реформе полиции и внутренней безопасности, в то время как НАТО занимается военными вопросами ${ }^{32}$.

Совет ЕС подтвердил, что вступление кандидатов будет зависеть от выполнения тех же требований, которые применялись к государствам ЦВЕ. Важно отметить, что в конце 2004 года ответственность за ЗБ была передана новому комиссару по расширению ЕС Олли Рену. Переход от послевоенной стабилизации к программе расширения обеспечил два важных преимущества по сравнению с прежней политикой управления конфликтами. Во-первых, рассмотрение ситуации на ЗБ как вопроса расширения, а не внешней политики позволило европейским институтам и государствам-членам ЕС уменьшить двусмысленность и расхождения в предпочтениях ${ }^{33}$. Во-вторых, обещание ассоциации и возможного членства предоставило ЕС возможность использовать полную силу политической обусловленности. В целом политика ЕС в регионе была метко охарактеризована как «условная поддержка реформ в направлении европеизации». ${ }^{34}$.

Беспокойство по поводу неподготовленных кандидатов в ЦВЕ привело к ужесточению условий ЕС еще до расширения в 2007 году, связанного с Болгарией и Румынией. В своей Стратегии расширения 2005 года ЕК подчеркнула три основных принципа своего подхода к дальнейшему расширению: консолидация политических обязательств, строгие, но справедливые, условия и лучшее общение. В Стратегии 2005 года также четко указано, что ЕК не планирует дальнейшего расширения с большой группой стран и что способность ЕС

31 EU-Western Balkans Summit at Thessaloniki, see Bull. EU 6-2003,

32 M. Sahlin, 'NATO and EU align Balkan agenda', Institute for War and Peace Reporting, 20 April 2005

33 Centre for European Policy Studies, 'The reluctant debutante: the European Union as promoter of democracy in its neighbourhood', CEPS Working Document 223, Brussels, July 2005

34 Van Meurs, W. P. The next Europe: South-Eastern Europe after Thessaloniki / W. P. Van Meurs - South East Europe Review, №6(3), 2003 
принимать новых членов представляет собой важный фактор ${ }^{35}$. Этот подход стал известен как «Новый консенсус по расширению», представляющий базовую основу для дальнейшей разработки стратегий расширения ЕС.

Стратегию расширения Комиссия в 2006 году укрепила условиями ЕС во время переговоров о вступлении за счет широкого использования критериев. Появились измеримые цели, которые должны быть выполнены странамикандидатами и которые связаны с ключевыми элементами на переговорах. В целом, введенные начальные критерии касаются ключевых подготовительных шагов для будущего согласования с «acquis communautaire», в то время как ранее существующие заключительные критерии, в первую очередь, касаются законодательных мер, административных или судебных органов и послужного списка, связанного с выполнением «acquis communautaire» ${ }^{36}$. Использование контрольных показателей усилило роль государств-членов в процессе расширения, поскольку они увеличили свою роль в утверждении и оценке соответствия критериям, требуемым странами-кандидатами на вступление в $\mathrm{EC}^{37}$. Кроме того, по сравнению с расширением за счет стран ЦВЕ увеличилось количество случаев, когда в государствах-членах Совета блокирующие решения по расширению возросли, и это относится не только к использованию контрольных показателей, но и к прогрессу на этапе, предшествующем переговорам ${ }^{38}$. От заявки на членство до вступления государства-члены должны единодушно договориться не менее чем по 75 пунктам. Оценивая эту ситуацию, Корина Стратулат пришла к выводу, что «Совет заменил Комиссию в качестве движущей силы политики расширения, которая сделала процесс расширения гораздо более непредсказуемым» ${ }^{39}$.

С 2011 года в рамках стратегии расширения ЕК стала уделять больше внимания вопросам первостепенной важности. Стратегия расширения 2011 года определила верховенство права как одну из основных проблем на всех этапах процесса присоединения. С этой целью Комиссия подчеркнула, что вопросы, связанные с судебной системой и основными правами, а также с правосудием и внутренними делами (борьба с коррупцией, борьба с организованной преступностью, реформа государственного управления и т. д.) должны решаться

35 European Commission, Enlargement Strategy Paper, COM (2005) 561 final, Brussels, 9 November 2005,

36 European Commission, Enlargement Strategy and Main Challenges 2006-2007, COM (2006) 649, Brussels, 8 November 2006,

37 Christophe H., op. cit. note 14 p./

${ }^{38}$ BiEPAG - Balkans in Europe Policy Advisory Group, The Unfinished Promise: Completing the Balkan Enlargement, May, Centre for Southeast European Studies, European Fund for the Balkans

39 Council of the European Union, Negotiating Framework: Principles Governing the Negotiations with the Republic of Serbia, Brussels, 2013 
на ранних этапах процесса вступления, и что соответствующие главы должны быть открыты на основе планов действий, поскольку они требуют установления убедительных результатов ${ }^{40}$.

В следующем году Стратегия расширения была сфокусирована на экономическом управлении, конкурентоспособности и росте. Комиссия заявила, что она постепенно адаптирует экономический надзор за странами, участвующими в расширении, с усилением экономического управления в $\mathrm{EC}^{41}$. Наконец, в 2013 году особое внимание было уделено функционированию институтов, гарантирующих демократию ${ }^{42}$.

В 2014 году президент ЕК Жан-Клод Юнкер объявил, что ЕС не будет расширяться в ближайшие пять лет. Это решение вызвало разногласия в ЕС, поэтому канцлер Германии Ангела Меркель выступила с дипломатической инициативой, получившей название «Берлинский процесс», который должен играть роль сохранения отношений между странами ЗБ и странами ЕС для поддержания европейской перспективы данного региона. Берлинский процесс состоит из ежегодных встреч на высшем уровне между правительствами стран ЗБ и нескольких стран-членов ЕС в период с 2014 по 2018 год, направленных на подтверждение позиции ЕС в регионе путем улучшения сотрудничества и экономической стабильности.

Между тем, ЕС столкнулся с рядом проблем, которые не имеют прямого влияния на политику расширения. Например, это такие события, как экономический кризис, кризис еврозоны, украинский кризис, кризис беженцев, BREXIT, украинский кризис и так далее. В новых условиях ЕС начал избегать ранее установленной практики прогнозирования, когда может произойти новое расширение. Такая позиция предполагает, что политика расширения не является таким сильным приоритетом, как раньше, и нынешний кризис является одной из причин сложившейся ситуации.

\section{4. Что происходит на Балканах?}

Анализируя историю расширения ЕС, мы можем сделать вывод, что процесс расширения постоянно усложняется и даже, порой, становится невозможным.. Настоящие события вокруг Западных Балкан ставят под сомнение необходимость расширения ЕС. После объявленного пятилетнего перерыва в расширении мы наблюдаем политику, которая продолжает двигаться в том же направлении. Почему это так?

40 European Commission, Enlargement Strategy and Main Challenges 2011-2012, COM (2011) 666 final, Brussels 12 October, 2011

41 European Commission, Enlargement Strategy and Main Challenges 2012-2013, COM (2012) 600 final, Brussels 10 October, 2012,

42 European Commission, , Enlargement Strategy and Main Challenges 2013-2014, COM (2013) 700 final, Brussels 16 October, 2013a 
Возвращаясь к основанию ЕС, необходимо отметить, что Союз в своих самых ранних договорах (первая форма) функционировал как экономический союз. Это означает, что главный элемент функционирования союза основан на экономической выгоде. Поэтому предполагается, что ЕС не будет принимать положительного решения, если не произойдет развития его экономики. История ЕС показывает, что во всех процессах расширения экономические выгоды для Союза имеют первостепенное значение (например, расширения в 1973 и 1995 годах) или являются одним из нескольких основных причин расширения. Следовательно, возникает вопрос, какие экономические выгоды получает ЕС от интеграции стран ЗБ? Нет сомнений в том, что страны ЗБ имеют экономические стандарты, намного ниже стандартов ЕС. Независимо от огромных ресурсов, выделенных для поддержки и развития экономики в регионе, до тех пор, пока ЕС не будет иметь необходимых экономических выгод, интеграция ЗБ остается невозможной.

В то же время можно выделить геополитическую позицию как один из основных драйверов интеграционной политики ЕC, которая уже являлась ключевым фактором в расширениях в 1981, 2004 и 2007 годах.

Относительно критериев расширения в 1981-ом году: Греция управлялась военной хунтой до 1974-ом года и подала заявку на членство в ЕС (ЕЭС) в следующем году. Греция выполнила основное требование демократической системы только формально. Основной причиной вступления Греции в ЕС (ЕЭС) стала борьба между двумя блоками в период холодной войны. Так как другие государства на Балканах принадлежали к социалистической системе управления (хотя некоторые из них имели тенденцию ассоциироваться с государствами третьего мира), единственное государство, которое могло извлечь выгоду и вернуть западное влияние на Балканах, была Греция. В результате идеологической и геополитической борьбы между двумя блоками Греция стала членом ЕС (ЕЭС) в 1981 году, несмотря на замечания о готовности к членству. Если сегодня сравним готовность и демократические возможности стран-кандидатов для членства в ЕС, а также готовность и демократические возможности Греции на момент ее вступления в ЕС (ЕЭС), мы заметим, что в этот момент у Греции было гораздо меньше демократических возможностей, чем у стран-кандидатов сегодня. Остается фактом - в то время не существовало копенгагенских критериев, а после их принятия интегрируемые страны не подлежали проверке на соответствие самим этим критериям.

Если мы посмотрим на геополитическую роль крупнейшего расширения в 2004 и 2007 годах и упомянем, что это расширение было тесно связано с членством в НАТО, то не секрет, что наиболее важной ролью ЕС в расширении было устранение влияния России в Европе и экспансия западных ценностей. Несомненно, не все страны отвечали европейским требованиям одинаково, у каждой страны был дефицит по разным стандартам в разных областях, 
но цель доминирования западных ценностей в странах ЦВЕ и обеспечения безопасности, которые бы обеспечили защиту ЕС от внешнего врага, были важнее, чем собственные ценности. В этом контексте страны ЗБ не имеют важной геополитической позиции, которая отвечает интересам ЕС для их интеграции. Присоединение некоторых из этих стран к НАТО гарантирует безопасность $\mathrm{EC}$, и является причиной больше, что ЕС теряет интерес к интеграции этого региона.

В контексте геополитики также необходимо отметить ту роль, которую балканские государства играют на Ближнем Востоке. Когда разразился кризис беженцев, некоторые еврооптимисты считали, что это было причиной объединения Европы. Но так ли это? А именно, если балканские страны (включая Турцию) интегрированы, тогда ЕС в качестве своих соседей получит ближневосточные государства, которые не являются безопасными ни с военной точки зрения, ни с политической, а наоборот, будут способствовать миграции своих граждан в Западную Европу. В случае не интеграции балканских стран они будут выступать в качестве границы с этим нестабильным регионом и препятствовать потоку мигрантов. По этой причине в интересах ЕС, чтобы эти страны оставались не интегрированными. Геополитические аспекты на самом деле показывают, насколько важна геополитическая позиция. В условиях геополитической нестабильности ЕС имеет значительно более низкие критерии интеграции и даже готов отойти от своих ценностей в контексте геополитического интереса. В настоящее время страны - кандидаты в члены ЕС не имеют существенного значения, что исключает заинтересованность ЕС в их интеграции.

Являются ли демократические возможности, которые неоднократно подвергались критике со стороны ЕК, непреодолимым препятствием? Помимо примера Греции (уже упоминавшегося), не следует забывать, что Испания и Португалия были интегрированы в ЕС (ЕЭС) несколько лет спустя, следуя примеру Греции, после краха режимов в обеих странах с недостаточным демократическим потенциалом. Примером этого в недавней истории ЕС является расширение в 2007 году, когда Румыния и Болгария также стали членами. Отчет ЕК по мониторингу 2006 показал, что необходимо добиться прогресса во многих сегментах судебной системы, в борьбе с коррупцией и организованной преступностью, и что эти сегменты будут продолжать отслеживаться. Таким образом, после их официального приема ЕК продолжала контролировать страны, в частности по отношении верховенства права, подтверждая то, что расширение было основано больше на политическом решении, чем на критериях, изложенных в Копенгагене. Также оказалось, что в случае несоответствия критериям, ЕС может найти политическое решение для интеграции конкретного государства, но данная практика не соотносится с другими кандидатами на Балканском полуострове. 
Право вето, применяемое государствами-членами ЕС, стало основой для защиты национальных интересов за счет интегрирующихся государств. Нет балканского государства, которое в какой-то момент своей интеграции не получило вето или угрозу вето, если оно не отвечает определенным условиям, требуемым государством, ранее интегрированным в ЕС. Во время последнего расширения, Хорватия, которая имеет открытые пограничные споры, столкнулась с такой проблемой. Словения как член ЕС угрожала и даже блокировала переговоры ЕС с Хорватией, поскольку пограничный спор по поводу «Пиранского залива» полностью не разрешился. Такая позиция ставила Хорватию в подчиненное положение, заставляя идти на уступки, с которыми она не соглашается в споре, указывая на неравные позиции на переговорах и давая возможность для открытых злоупотреблений в процессе интеграции.

В аналогичной ситуации Сербия оказалась вынуждена регулировать права румынской этнической общины. Страна с худшим подобным опытом - Македония, которая не могла начать переговоры с ЕС из-за спора о названии страны. С 2009 по 2014 год Македония на каждом саммите получала позитивную рекомендацию ЕК о начале переговоров, и на каждом саммите Греция накладывала вето, а в 2012 году Болгария присоединилась к осуществлению своего права вето для защиты своих национальных интересов, на счет интеграционного процесса Македонии. Использование права вето показало слабость в политике интеграции в ЕС, которая может быть преодолена в том случае, если право вето будет дополнено негативным влиянием на ЕС. До настоящего времени практика показала злоупотребление вето в отношении любого двустороннего спора в ущерб государству, имеющему кандидатский статус, и привилегию ранее интегрированного государства. Напротив, если равенство является ценностью, то необходимо, чтобы двусторонние споры были разрешены либо полностью вне ЕС, либо полностью внутри (после интеграции) ЕС, где все стороны равны.

Специфической является ситуация с Турцией, которая в настоящее время сталкивается не с классическим вето в качестве препятствия, а с другим инструментом, использующим право вето. В мае 2008 года Франция изменила свою конституцию, сохранив положение о референдуме только для стран, население которых составляет более 5 процентов от общей численности населения ЕС - таким образом, эффективно выделяя Турцию.

Особое значение следует уделять открытым вопросам, с которыми сталкивается балканское государство и которые представляют собой условие (или одно из условий) для вступления в ЕС. На переднем плане - проблема Косово и уже решенная проблема названия страны между Македонией и Грецией.

Что касается косовского вопроса, то Сербия сталкивается не с проблемой, напрямую связанной с государством ЕC, а с одним из условий интеграции - 
добрососедскими отношениями. Следовательно, ЕС не позволяет интеграции Сербии без разрешения спора, и в то же время не предлагает приемлемого решения для государства. Данная практика отличается от ранее сложившейся практики интеграции в отношении проблем с самопровозглашенными государствами на территории страны-кандидата на вступление в ЕС. Асимметричный случай 2004 года связан с интеграцией Кипра в ЕС. Кипр вступил в ЕС, хотя спор с самопровозглашенной Турецкой Республикой Северного Кипра оставался неразрешенным на его территории. Единственное существенное отличие, которое можно увидеть в этих примерах, заключается в том, что некоторые члены ЕС признали Косово как государство, а Кипр - нет.

В отличие от этого примера имеется случай коллективного требования ЕС. Вопрос о названии страны между Македонией и Грецией имеет конкретный запрос ЕС (разрешение спора и установление добрососедских отношений), но условие для разрешения этого спора полностью устанавливается конкретным государством, а именно Грецией. Такая политика дополнительно повлияла на поведение Болгарии в отношении Македонии. Болгария в 2012 году наложила вето на рекомендацию начать переговоры с Македонией, с тем чтобы впоследствии добиваться создания нового двустороннего соглашения о добрососедстве, в котором требования предъявлялись непосредственно к истории и идентичности Македонии. В установленной практике ЕС не было таким случаев. Необходимо отметить, что такие условия, как переименование государства, отказ от своей собственной территории для создания нового государства или изменение собственной истории, являются не только морально и этически неприемлемыми, но и представляют серьезную угрозу и подрыв национальной идентичности, культуры, что не имеет ничего общего с европейскими стандартами.

\section{5. Новая методология расширения ЕС}

Независимо от того, что общественности было заявлено - после уступок со стороны Македонии относительно спора о названии страны (между Македонией и Грецией) и подписания соглашения о добрососедских отношениях (между Македонией и Болгарией) - после выполнения всех условий начнутся переговоры с ЕС, этого не произошло. Октябрьский саммит 2019 года лидеров ЕС в Брюсселе закончился совсем по-другому: на этот раз Франция, за которой последовало несколько государств, заблокировавших начало переговоров с Македонией и объявивших о необходимости проведения в стране реформ. Таким образом, появилась новая методология для руководства переговорным процессом, что является еще одним свидетельством неравных критериев для кандидатов с Балканского полуострова на вступление в ЕС.

После октябрьского саммита ЕК дала рекомендации ЕС начать переговоры о вступлении Македонии и Албании в результате полного выполнения требований 
о вступлении. Однако Совет ЕС вновь решил заблокировать начало переговоров по вступлению в ЕС этих стран. Главным инициатором такого решения была Франция с предлогом того, что в настоящее время в ЕС приоритетным является разрешение внутренних проблем, а не проблем в странах-кандидатах.

Начало переговоров было заблокировано французами при поддержке нескольких других государств-членов. Обращаясь к общественности, президент Макрон сказал: «Перед любым расширением мы должны преуспеть в реформировании. Некоторые говорят, что мы только откроем дверь к переговорам, но это займет 10-15 лет, и я отвечу им, что методология не очень хорошая» ${ }^{43}$. В этом контексте аргументы, выдвинутые Макроном, имели достаточно обоснованный подход, и его цель оказалась устойчивой в долгосрочной перспективе.

Даже во время саммита, Макрон получил серьезную критику. Автором одной из предложенных идей был председатель Финляндии, который предложил одобрение переговоров и одновременное создание новой методологии. Самая жесткая была реакция президента ЕК Жан-Клод Юнкера, который, обращаясь журналистам в конце двухдневного саммита Совета ЕС, сказал: «Я очень разочарован результатом нашей дискуссии о расширении. Это серьезная историческая ошибка - серьезная историческая ошибка». И добавил: «Если мы хотим, чтобы нас уважали, мы должны выполнять свои обещания» ${ }^{44}$ - сказал Юнкер, говоря по-французски и используя повторение, чтобы подчеркнуть свою точку зрения.

Встреча между Макроном и Меркель состоялась два дня спустя: на этот раз Германия выступила в роли смягчителя французской позиции. Но и после этой встречи Макрон по-прежнему придерживался своей позиции: «Я думаю, что нам нужно изменить процедуру. Сегодня процесс необратим, не прогрессивен и не адаптирован» ${ }^{45}$. После этого европейские институты начали работу по новой методологии, а это утверждение стало одним из основных ее элементов.

После нескольких вариантов официальная методология была представлена в феврале 2020 года. Новая методология предусматривала, что процесс должен быть лучше подготовлен для устранения структурных недостатков в странах, в

${ }^{43}$ A grave historic error': Juncker hits out as North Macedonia and Albania have EU bids blocked [Электронный ресурс] URL: https://www.independent.co.uk/news/world/europe/ eu-enlargement-emanuel-macron-albania-north-macedonia-juncker-a9161536.html (дата обращения : 10.05.2020)

44 EU-Western Balkans summit: Is enlargement in sight? | Euronews Answers [Электронный ресурс] URL: https://www.euronews.com/2019/10/18/france-denmark-andnetherlands-block-albania-s-eu-membership-bid (дата обращения : 10.05.2020)

45 France rejects talks with Balkan hopefuls on EU membership [Электронный ресурс] URL: https://www.euronews.com/2019/07/05/eu-western-balkans-summit-is-enlargementin-sight-euronews-answers (дата обращения : 10.05.2020) 
частности в области основ. Чрезвычайно важно укрепить доверие между всеми заинтересованными сторонами, улучшить процесс вступления и сделать его более эффективным ${ }^{46}$.

Новая методология была определена как «оживлениепроцесса вступления»:

Больше доверия - это означает, что лидеры ЗБ должны более достоверно выполнять свои обязательства по осуществлению необходимых фундаментальных реформ;

Более сильное политическое управление - учитывая то, что поставлено на карту, пришло время поставить политический характер процесса на первый план и обеспечить более эффективное руководство и участие на высоком уровне со стороны государств-членов;

Более динамичный процесс - согласования глав будет организовано в тематических кластерах. Сгруппированные главы позволят уделить больше внимания основным секторам политического диалога и обеспечат более качественную основу для политического взаимодействия на более высоком уровне.

В отсутствие реформы и прогресса в переговорном процессе ЕС предусмотрел санкции:

- Государства-члень могут решить, что переговоры могут быть приостановлень в определенных областях или, в наиболее серьезных случаях, в иелом приостановлены. Уэе закрытые главы могут быть заново открыты, если необходимо пересмотреть проблемы;

- Объемиинтенсивность финансирования ЕСмогут быть скорректированы в сторону понижения, за исключением поддержки гражданского обиества;

- Преимущества более тесной интеграции, например, доступ к программам ЕС, односторонние уступки для доступа крынку могут быть приостановлень или отменены. Предсказуемость и обусловленность также будут улучшены за счет больией прозрачности ${ }^{47}$.

Мозговые центры, финансируемые брюссельскими фондами, начали миссию защиты новой методологии и ее представления в лучшем свете. Балканским СМИ рекомендовано не углубляться в существующие проблемы. Балканским лидерам ничего не остается, кроме как принять и приветствовать новую методологию.

46 European Commission - Enhancing the accession process - A credible EU perspective for the Western Balkans -

Brussels, 2020

47 European Commission - Enhancing the accession process - A credible EU perspective for the Western Balkans -

Brussels, 2020 
Правительство Северной Македонии считало, что новая методология это новая возможность. Такая позиция понятна после всех уступок, которые были сделаны властными институтами без учета национальных интересов, утраченных с единственной целью - начать переговоры. Методология была представлена исполнительной властью как уникальная возможность для переговоров.

В Сербии и Черногории ситуация не сильно отличалась. Разница в том, что новая методология не распространяется на страны, которые уже ведут переговоры. Но у этих двух стран остается возможность изменить ход переговоров и перейти на новую методологию. Сразу после введения новой методологии она была положительно оценена в политическом дискурсе. Одновременно возникли споры о том, целесообразно ли присоединяться к новой методологии. В качестве дополнительного фактора следует обратить внимание на заявления комиссара ЕС по расширению, который мягко, но прямо указывает, что для стран, ведущих с ЕС переговоры, лучше продолжить процесс в соответствии с новой методологией.

Мало кто в публичном и политическом дискурсе обратил внимание на негативные аспекты новой методологии. Принимая ее ЕС практически указывает на многие свои слабые стороны и неравноправие в поведении по отношению к странам ЗБ. На пример, в документах ЕК отдается предпочтение «более предсказуемым, более заслуживающим доверия - на основе объективных критериев и строгих положительных и отрицательных условий и обратимости - более динамичным и подкрепленным более сильным политическим руководством» ${ }^{48}$. При этом подчеркивается , что ЕС указывает на отсутствие объективных критериев в процессах, проведенных по сей день. Подчеркивая термин «более сильным политическим руководством» ${ }^{49}$, который упоминается в нескольких различных контекстах в документе, предполагается, что интеграция стран не будет основываться на их праве стать частью ЕС в рамках законодательства, но указывает на то, что процесс основан исключительно на политических решениях, которые снова делают результат совершенно неопределенным.

Самым спорным моментом является то, что ЕС имеет право санкционировать, заморозить или полностью сорвать переговорный процесс. Практически это означает, что государства должны полностью основывать свою политику на выполнении требований ЕС, теряя право защищать свои национальные интересы. Если государства, участвующие в процессе, защищают свои национальные интересы, что не отвечает интересам ЕС, то они получат

${ }^{48}$ European Commission - Enhancing the accession process - A credible EU perspective for the Western Balkans -

Brussels, 2020

49 Там же 
негативную оценку, и теряют свой статус кандидата в члены ЕС.

Соответственно, процесс становится полностью политическим, выходит из правовых рамок, а государственная политика будет полностью регулироваться интересами ЕС.

\section{Заключение}

Процесс расширения ЕС не является исключительно территориальным расширением, а включает получение прав, привилегий и обязательств из членства и представляется долгим, утомительным, бюрократическим и техническим процессом который включает гораздо больше обязанностей по отношению к странам-кандидатам.

Исторический и сравнительный анализ свидетельствует о неодинаковом поведении ЕС в отношении стран-кандидатов на членство, нарушающем принцип равенства. Политика расширения полностью отклоняется от ценностей ЕС и является преимущественно политическим соглашением и политическим решением. Также можно сделать вывод, что постоянные изменения и добавления новых правил игры сделали процесс интеграции слишком сложным для стран, экономические и политические возможности которых представляются как скромные.

Анализируя балканские реалии и позиции стран ЕС в отношении проведения и оценки стран-кандидатов на основе контент- и интент-анализа, выяснилось, что государства члены ЕС используют свою позицию и влияют на решения в отношении оценки стран-кандидатов на вступление, чтобы защитить свои национальные интересы в двусторонних спорах. Одновременно право вето является неограниченным, и объективность его использования неизмерима, что позволяет субъективно использовать его для защиты своих интересов, что не совпадает с ценностями или интересами ЕС. Существует необходимость в ограничении использования права вето, без такого ограничения процесс интеграции может принести больше вреда, чем пользы странам-кандидатам.

В новой методологии расширения ЕC впервые появляется право санкционировать, заморозить или полностью сорвать переговорный процесс. Проблема заключается в том, что государства должны полностью основывать свою политику на выполнении требований ЕC, теряя право на защиту своих национальных интересов. Если государства, участвующие в процессе, защищают свои национальные интересы, а это не отвечает интересам ЕС, они потеряют свой статус. 


\section{Список литературы:}

\section{1. Книги и статьи}

1. Anastasakis, O. EU Conditionality in South East Europe: Bringing Commitment to the Process / O. Anastasakis, D. Bechev- Oxford, SEESP - 2003

2. Axel Sotiris Walldén [Электронный pecypc] - The demise of EU enlargement policy - $2017 \quad$-http://www.eliamep.gr/wp-content/uploads/2017/03/ Enlargement-policy-1701-fin.pdf, (дата обращения : 02.05.2020)

3. Batt et al. The Western Balkans: Moving On / Batt - Chaillot Paper №. 70, Institute for Security Studies, Paris, - 2003

4. Борко, Ю. [Электронный ресурс] История развития европейского союза / Ю . Борко, О. Буторина - М . 2009 - [Электронный ресурс] URL: https:// mgimo.ru/uploads/files/Borko_Butorina_Istoriya_ES.pdf (дата обращения : 04.05.2020)

5. Christophe, H. 2011. "EU Enlargement" / H. Christophe - Swedish Institute for European Policy Studies; OUP CORRECTED PROOF - 2011

6. Christophe, H. The Creeping Nationalization of The EU Enlargement Policy / H. Christophe - Swedish Institute for European Policy Studies - Report No. $6-2010$

7. Маролов, Д. Проширување на ЕУ - Историски приказ и моментална состојба / Д. Маролов, С. Стојановски - Универзитет „Гоце Делчев” Штип $-2018$

8. Moreno, A.J. Franco's Spain and the European Communities / A.J. Moreno - [Электронный ресурс] - http://www.europarl.europa.eu/RegData/etudes/ STUD/2015/563509/EPRS_STU(2015)563509_EN.pdf, (дата обращения : $05.05 .2020)$

9. Leki, C. The accession of Greece, Greece in Europe: a short history/ C. LikI - [Электронный pecypc]- URL : https://www.theguardian.com/world/2015/ jul/03/greece-in-europe-a-short-history, 2016 (дата обращения : 05.05.2020)

10. Pop, V. EU commission defends Romania-Bulgaria monitoring project / V. Pop - [Электронный ресурс] , URL - https://euobserver.com/justice/29743, (дата обращения : 05.05.2020)

11. Sahlin, M. 'NATO and EU align Balkan agenda', Institute for War and Peace Reporting, 20 April 2005

12. Стрежнева. М.В. Теории европейской интеграции / М.В. Стрежнева // Вестн. М. ун-та. Сер. 25. Международные отношения и мировая политика - 2009. № 1 - 30.c.

13. Van Meurs, W. P. The next Europe: South-Eastern Europe after Thessaloniki / W. P. Van Meurs - South East Europe Review, №6(3), 2003 


\section{2. Нормативные правовые акты и другие официальные документы}

1. Accession Criteria (Copenhagen Criteria) - EUR-Lex". 2018. Eur-Lex. europa. eu. URL: http://eurlex.europa.eu/summary/glossary/accession_criteria copenhague.html (дата обращения : 05.05.2020)

2. BiEPAG - Balkans in Europe Policy Advisory Group, The Unfinished Promise: Completing the Balkan Enlargement, May, Centre for Southeast European Studies, European Fund for the Balkans

3. Centre for European Policy Studies, 'The reluctant debutante: the European Union as promoter of democracy in its neighbourhood', CEPS Working Document 223, Brussels, July 2005

4. Conditions for Membership - European Neighborhood Policy and Enlargement Negotiations - European Commission". 2018 URL: https://ec.europa.eu/ neighbourhood-enlargement/policy/conditions-membership en _ (дата обращения : 04.05.2020)

5. Council of the European Union, Negotiating Framework: Principles Governing the Negotiations with the Republic of Serbia, Brussels, 2013,

6. European Commission, Enlargement Strategy Paper, COM (2005) 561 final, Brussels, 9 November 2005,

7. European Commission, Enlargement Strategy and Main Challenges 2006-2007, COM (2006) 649, Brussels, 8 November 2006,

8. European Commission, Enlargement Strategy and Main Challenges 2011-2012, COM (2011) 666 final, Brussels 12 October, 2011,

9. European Commission, Enlargement Strategy and Main Challenges 2012-2013, COM (2012) 600 final, Brussels 10 October, 2012,

10. European Commission, , Enlargement Strategy and Main Challenges 20132014, COM (2013) 700 final, Brussels 16 October, 2013a,

11. European Commission - Enhancing the accession process - A credible EU perspective for the Western Balkans -

12. Brussels, 2020,

13. European Commission, Western Balkans: Prospect of EU Membership Incites Peace in the Western Balkans, 2006,

14. Interim report from the commission to the council and the European parliament on reforms in Croatia in the field of judiciary and fundamental rights (negotiation chapter 23),

15. Ministry of foreign affairs Directorate for EU affairs Republic of Turkey Enlargement of the European Union

16. Monitoring report on the state of preparedness for EU membership of Bulgaria and Romania, URL - http://news.bbc.co.uk/2/shared/bsp/hi/pdfs/26 0906 fullreport.pdf, (дата обращения : 05.05.2020) 
17. Policy Department, Directorate-General for External Policies - The Western Balkans and EU Enlargement: Lessons learned, ways forward and prospects ahead / European Union, 2015,

18. The history of the European Union [Электронный ресурc] -URL: https:// europa.eu/european-union/about-eu/history_en (дата обращения : 05.05.2020)

\section{3. Электронные ресурсы (интернет страницы)}

1. A grave historic error': Juncker hits out as North Macedonia and Albania have EU bids blocked URL: https://www.independent.co.uk/news/world/europe/ eu-enlargement-emanuel-macron-albania-north-macedonia-juncker-a9161536. $\underline{\mathrm{html}}$ (дата обращения : 10.05.2020)

2. France rejects talks with Balkan hopefuls on EU membership URL: https://www. euronews.com/2019/10/18/france-denmark-and-netherlands-block-albania-seu-membership-bid (дата обращения : 10.05.2020)

3. EU-Western Balkans summit: Is enlargement in sight?| Euronews Answers URL: https://www.euronews.com/2019/07/05/eu-western-balkans-summit-isenlargement-in-sight-euronews-answers (дата обращения : 10.05.2020) 